\title{
The Comparative Economic Profitability of CU Crops Vis-a-Vis SW and GW Crops in Karnataka: Partial Budgeting Analysis
}

\author{
M. N. Venkataraman ${ }^{1}$, L. Muralidhar ${ }^{2}$, A. D. Ranganatha $^{1}$ and B. Gururaj ${ }^{1 *}$ \\ ${ }^{1}$ Department of Agricultural Economics, UAS, GKVK Bangalore, India \\ ${ }^{2}$ Department of Agri Extension, V.C Farm Mandya, UAS Bangalore, India \\ *Corresponding author
}

\section{A B S T R A C T}

\section{Keywords \\ Conjunctive use of water, Income, Sustainability, Surface water \\ Article Info \\ Accepted: 12 November 2020 Available Online: 10 December 2020}

\begin{abstract}
Conjunctive use is a single input to address the physical and economic scarcity of surface water (SW) and groundwater $(\mathrm{GW})$ and it offers the solution to a large extent to hurtful effects of SW and GW. This study aims at addressing the importance of conjunctive use in enhance the income of the farmer. This study examines the comparative economics of crops (Sugarcane, Ragi and Paddy) under different regimes at farm level in Cauvery command area of Karnataka. The findings reveals that net gain realized by the sugarcane farmers under conjunctive use of water as against of surface and groundwater about Rs.774 and 34,233 per ac / year and it is same for Ragi and Paddy crop. Using production function analysis, the net returns realized was worked out. The results were revealed that the net returns realized per farm was more in CU use farmers (Rs.1, 51,594) followed by SW (Rs 38,237) and GW (Rs.32, 738). This signifies potential benefits of conjunctive use of water in realizing gross income of the farmers.
\end{abstract}

\section{Introduction}

In recent decades due to burgeoning population constantly increasing demand for food and provision of food security programme and demand for water from other sources in multiple times. In India, surface water meets only $30 \%$ of water requirement for irrigation and about $70 \%$ of the irrigation through groundwater (Chandrakanth, 2015) The Groundwater is an invisible resource till it is tapped and has relatively missed the attention of lawmakers, economists, agronomists and water resource specialist, as well as policies, programme, institutional structures in comparison with surface water. Surface water resources are limited due to their dependency on monsoon, except for rivers in Indo Gangetic plains where the perennial rivers (Ganga, Yamuna and Sutlej) and the rest of India dominated by hard rock's which are starved of both groundwater and surface water for all needs.

Currently, India is the largest exploiter of groundwater in the world next to United States and Europe. India pumps twice the groundwater pumped in the United States, and six times that pumped in the Europe Union. Since the groundwater resources are extracted 
indiscriminately, there have been massive initial and premature well failures in Peninsular India and Karnataka is no exception leading to sharp decline in the number of open wells and a sharp increase in a number of bore well failures. Only in exceptional circumstances in Krishna command area in Karnataka, dug/open well are still functioning. In the regions under Eastern and Central Dry Zones of Karnataka, the depth of the bore wells has gone up to the level of 1,500 feet and 2,000 feet in some areas. In many areas, micro irrigation methods (drip and sprinkler) are slowly catching up as a coping strategy for the economic scarcity of groundwater.

Studies conducted in the Department of Agricultural Economics, University of Agricultural Sciences, Bengaluru (Chandrakanth, 2009) on groundwater costing sponsored by the Ford Foundation, the cost range between Rs 200 and Rs 500 per ac inch, as these groundwater costs are calculated exclusively for areas anxious with negative externalities due to cumulative interference. Thus, the price of groundwater is around Rs 400 per ac inch at the current price for irrigation of which pumping costs constitute around 80 per cent of total cost of irrigation.

With the situation of economic scarcity of groundwater, farmers should improve their water use efficiencies rather than venturing on additional sources/s of groundwater, which is not only risky to strike but also has a serious impact on sustainability. So, overuse of both the sources of water would lead to the imbalance in water management and thereby efficiency goes down and its has detrimental effects on income of the farmers and their livelihood.

Conjunctive use is a situation where both groundwater and surface water are developed to supply a given irrigation canal-command - although not necessarily using both sources continuously over time not providing each individual water user from both sources. The conjunctive use as use of surface water and groundwater consists of harmoniously combining the use of both sources of water in order to minimize the undesirable physical, environmental and economic effects of each solution and to optimize the water demand/supply balance. (Jahangir et al, 2003). Thus, Conjunctive use is a single input to address the physical and economic scarcity of surface water (SW) and/or groundwater (GW) and it offers the solution to a large extent to hurtful effects of SW and GW.

This study aims at addressing the importance of conjunctive use to tackle the problem of imbalance in water by which we can minimize the dependency on a single source of water and to enhance the income of the farmer. This study examines the comparative economics of crops (Sugarcane, Ragi and Paddy) under different regimes at farm level in the study area. This findings of the study acknowledges parity between both agronomical objective of 'more crop per drop' and economic objective of 'maximizing net returns per rupee of water.

\section{Materials and Methods}

\section{Sampling method}

The present study was carried out in the Mysuru and Mandya which fell under Cauvery command area. Simple random sampling technique was adopted for the selection of sample farmers. About 180 farmers were selected of which, 20 each sugarcane and ragi farmers under surface water (SW) groundwater (GW) and conjunctive use regime (CU) whilst 30 each paddy farmers under surface and conjunctive use of water during 2018-19 in the study area. 


\section{Partial budgeting}

Partial budgeting is one of the most widely used techniques to understand the profitability because of the change in the existing technology. It focuses only on the changes in income and expenses that would result from implementing an alternative technology. Thus, all components of farm profits which remain unchanged by the decision can be ignored. In a nutshell, partial budgeting allows us to get a better idea of how a decision can affect the profitability of the farm. However, the value of a partial budget analysis is highly dependent upon the quality of the information used in the analysis. In this study, the impact of different irrigation regimes followed by farmers is evaluated using the partial budgeting approach. The technique considers the additional costs involved under different irrigation regimes and incremental returns realized by different irrigation regimes. The difference indicates the profitability due to particular kind of irrigation method.

\begin{tabular}{|c|c|}
\hline Debit & Credit \\
\hline $\begin{array}{c}\text { Increase in cost due to particular irrigation } \\
\text { method in the farm = A }\end{array}$ & $\begin{array}{c}\text { Decrease in cost due to particular irrigation } \\
\text { method in the farm = C }\end{array}$ \\
$\begin{array}{c}\text { Decrease in gross returns due to particular } \\
\text { irrigation method in the farm = B } \\
\text { Total = A+B }\end{array}$ & $\begin{array}{c}\text { Increase in gross returns due to particular } \\
\text { irrigation method in the farm = D } \\
\text { Total = C+D }\end{array}$ \\
\hline Credit minus debit = Net gain / loss \\
\hline
\end{tabular}

\section{Profitability of irrigation regimes}

To find out the profitability of each irrigation regimes, common crops grown in each regime were considered. Average per ac costs and returns were worked out from the selected common crops and partial budget technique was employed to find the net gain or loss from the technology.

\section{Production function analysis}

Linear Dummy variable regression model was employed to know the contribution of different irrigation regimes to the farm's net returns.

$Y=\beta_{0}+\beta_{1} X+\beta_{2} D_{1}+\beta_{3} D_{2}+\beta_{4} D_{1} X+\beta_{5} D_{2}$ $\mathrm{X}$

Where,

Y represents net returns (')

$\mathrm{X}$ represents water used in ac inch
$\mathrm{D}_{1}$ represents intercept dummy for conjunctive use. It takes the value 1 for conjunctive use and takes the value 0 for control farms without conjunctive use. It captures the shift in intercept due to technology.

$\mathrm{D}_{2}$ represent intercept dummy for groundwater irrigation. It takes the value 1 for farms which depend exclusively on groundwater irrigation and takes the value 0 for control farms which do not depend exclusively on groundwater irrigation. It captures the shift in intercept due to technology.

$\mathrm{D}_{1} \mathrm{X}$ and $\mathrm{D}_{2} \mathrm{X}$ represent slope dummies which capture the rate of increase in net returns per farm due to water use in conjunctive use and groundwater irrigation respectively. They explicitly measure the marginal productivity of groundwater due to conjunctive use and groundwater irrigation. 
$\beta_{0}, \beta_{1}, \beta_{2}, \beta_{3}, \beta_{4}, \beta_{5}$ are the regression coefficients.

\section{Results and Discussion}

\section{Profitability of irrigation regimes using the partial budget technique}

Partial budgeting is one of the most widely used techniques to understand the profitability because of the change in the existing technology. Here the impact of different irrigation regimes followed by farmers is evaluated using this technique.

The technique considers the additional costs involved under different irrigation regimes and incremental returns realized by different irrigation regimes. To find out the profitability of each irrigation regimes, common crops grown in each regime were considered with average per ac costs and returns. Similarly, the net gain or loss was worked out from the used technology.

\section{Profitability of sugarcane crop of $\mathrm{CU}$ farms over GW}

Increase in the cost due to $\mathrm{CU}$ was the sum difference between costs of machine labour, human labour which account of about Rs.962. Since CU enables farmers to cultivate across all seasons. Increase in returns due to $\mathrm{CU}$ was the sum difference between the gross returns obtained by CU farmers and SW farmers.

The total additional returns realized by the CU farms were Rs. 23,198 per ac due to higher production Thus, the profitability of $\mathrm{CU}$ over GW was assessed by subtracting total expenses from total savings. The economic benefit realized by $\mathrm{CU}$ farmers over SW farmers which accounted to Rs. 34,233 per ac per year (Table 1). The profitability of CU farms over SW farms in the current study is in close conformity with the findings of
Suhas (2017). Similarly profitability of sugarcane crop under conjunctive use of water as against of surface water the addition expenses incurred by farmer of about Rs. 9152 per acre and additional returns were realized of about Rs.6057 thus, the net gain realized by cane farmers under conjunctive use of water of about Rs.774 per acre indicated in table 2 .

\section{Profitability of Ragi crop}

The economic profitability of conjunctive use of Ragi crop over surface and groundwater in Cauvery command area indicated in the table 3 and 4 . The findings clearly indicates that conjunctive use of water ragi farmers incurs of Rs 6507 additional expenses towards ragi cultivation as compared to surface water and additional gross returns realized of Rs. 9287 perhaps due to improvement in yield level and due to less cost incurred in FYM and seeds thus conjunctive use of water ragi farmers realized net gain of about Rs. 3,931 in the study area whilst conjunctive use of ragi farmers realized about Rs.1913 over groundwater. This acknowledges conjunctive use of water farmers are better off in terms of gross income as compared to surface and groundwater in the study area.

\section{Profitability of paddy}

The economic profitability of conjunctive use of paddy crop over surface in Cauvery command area indicated in the table 5. The findings clearly indicate that conjunctive use of water paddy farmers incurs of Rs 4967 as additional expenses as compared to surface water due to additional cost (Machine and FYM and Irrigation cost). Additional returns realized of Rs. 1886 due to higher yield in totally net gain realized of about Rs. 1253 per acre. 
Table.1 Estimated profitability of sugarcane crop of CU over GW (Rs/acre)

\begin{tabular}{|c|c|c|c|}
\hline Debit & $\begin{array}{c}\text { Amount } \\
\text { (in Rs) }\end{array}$ & Credit & $\begin{array}{l}\text { Amount } \\
\text { (in Rs) }\end{array}$ \\
\hline \multicolumn{2}{|c|}{$\begin{array}{l}\text { Increase in cost } \\
\text { (Additional cost due to } \mathrm{GW} \text { over } \mathrm{CU} \text { ) }\end{array}$} & \multicolumn{2}{|c|}{$\begin{array}{l}\text { Decrease in cost } \\
\text { (Reduced cost due to CU over GW) }\end{array}$} \\
\hline Machine labor (Rs. 6960 - Rs.7544) & 584 & Seeds (Rs.9240 - Rs.10420) & 1180 \\
\hline \multirow[t]{5}{*}{ Human labor (Rs. 11853 - Rs.11475) } & 378 & FYM and Silt (Rs.9840 - Rs12340) & 2500 \\
\hline & & Bullock labor (Rs.3360 - Rs.2873) & 487 \\
\hline & & Irrigation cost (Rs.15160 - Rs 7330) & 7830 \\
\hline & & \multirow{2}{*}{$\begin{array}{l}\text { Increase in gross returns } \\
\text { (Additional gross returns due to CU } \\
\text { over GW) (Rs.1,21,635 - Rs. } \\
98,437 \text { ) }\end{array}$} & \\
\hline & & & 23,198 \\
\hline Total expenses & 962 & Total savings & 35,195 \\
\hline \multicolumn{4}{|c|}{ Net gain $=$ Total expenses - Total savings $=$ Rs $\mathbf{3 4 , 2 3 3}$} \\
\hline
\end{tabular}

CU: Conjunctive use of water; GW- Ground Water

Table.2 Estimated profitability of sugarcane crop of CU farms over SW (Rs/acre)

\begin{tabular}{|c|c|c|c|}
\hline Debit & Amount (Rs) & Credit & Amount (Rs) \\
\hline \multicolumn{2}{|c|}{$\begin{array}{l}\text { Increase in cost } \\
\text { (Additional cost due to } \mathrm{SW} \text { over } \mathrm{CU} \text { ) }\end{array}$} & \multicolumn{2}{|c|}{$\begin{array}{l}\text { Decrease in cost } \\
\text { (Reduced cost due to CU over SW) }\end{array}$} \\
\hline Seeds (Rs. 9138 - Rs. 9240) & 102 & $\begin{array}{l}\text { Bullock labor cost } \\
\text { (Rs.2972- Rs. 2873) }\end{array}$ & 99 \\
\hline Machine labor (Rs. 7544 - Rs. 5658) & 1886 & $\begin{array}{l}\text { Human labor cost (Rs. } \\
11853 \text { - Rs.15623) }\end{array}$ & 3770 \\
\hline FYM and silt cost (Rs.9840 - Rs 8756) & 1084 & & \\
\hline \multirow[t]{2}{*}{ Irrigation cost (Rs.7330 - Rs.1250) } & 6080 & & \\
\hline & & $\begin{array}{l}\text { Increase in gross returns } \\
\text { (Additional gross returns } \\
\text { due to CU over GW) } \\
\text { (Rs.121635 - Rs.115578) }\end{array}$ & 6057 \\
\hline Total expenses & 9152 & Total savings & 9926 \\
\hline
\end{tabular}

CU: Conjunctive use of water; SW- Surface Water 
Table.3 Estimated profitability of Ragi crop of CU farms over SW (Rs/acre)

\begin{tabular}{|c|c|c|c|}
\hline Debit & Amount (Rs) & Credit & Amount (Rs) \\
\hline \multicolumn{2}{|c|}{$\begin{array}{l}\text { Increase in cost } \\
\text { (Additional cost due to } \mathrm{CU} \text { over } \mathrm{SW} \text { ) }\end{array}$} & \multicolumn{2}{|c|}{$\begin{array}{l}\text { Decrease in cost } \\
\text { (Reduced cost due to CU over SW) }\end{array}$} \\
\hline $\begin{array}{l}\text { Human labor cost (Rs.15751 - } \\
\text { Rs.11215) }\end{array}$ & 4536 & Seeds (Rs.340 - Rs.287) & 30 \\
\hline $\begin{array}{l}\text { Bullock labor cost (Rs.3627- } \\
\text { Rs. 2098) }\end{array}$ & 1529 & FYM and silt (Rs.4226- Rs.4870) & 644 \\
\hline $\begin{array}{l}\text { Fertilizers cost (Rs.2445 - } \\
\text { Rs.2029) }\end{array}$ & 416 & Marketing cost (Rs.1952 - Rs.1475) & 477 \\
\hline \multirow[t]{2}{*}{ Irrigation cost (Rs.268- Rs.242) } & 26 & & \\
\hline & & $\begin{array}{l}\text { Increase in gross returns } \\
\text { (Additional gross returns due to CU } \\
\text { over GW) (Rs.38266 - Rs.28979) }\end{array}$ & 9287 \\
\hline Total expenses & 6507 & Total savings & 10438 \\
\hline
\end{tabular}

SW: Surface water; CU: Conjunctive use of water

Table.4 Estimated profitability of Ragi crop of CU over GW (Rs/acre)

\begin{tabular}{|c|c|c|c|}
\hline Debit & Amount (Rs) & Credit & Amount (Rs) \\
\hline \multicolumn{2}{|c|}{$\begin{array}{l}\text { Increase in cost } \\
\text { (Additional cost due to } \mathrm{CU} \text { over GW) }\end{array}$} & \multicolumn{2}{|c|}{$\begin{array}{c}\text { Decrease in cost } \\
\text { (Reduced cost due to CU over GW) }\end{array}$} \\
\hline Seeds (Rs. 340 - Rs.287) & 53 & $\begin{array}{l}\text { Irrigation cost (Rs.3015 } \\
\text { - Rs.268) }\end{array}$ & 2747 \\
\hline Bullock labor cost (Rs.3627 - Rs. 933) & 2694 & $\begin{array}{l}\text { Machine cost (Rs.2988 } \\
\text { - Rs.2935) }\end{array}$ & 53 \\
\hline FYM and silt cost (Rs.4226 - Rs. 3860) & 366 & & \\
\hline Fertilizers cost (Rs. 2445 - Rs. 2229) & 216 & \multirow[b]{3}{*}{$\begin{array}{l}\text { Increase in gross } \\
\text { returns } \\
\text { (Additional gross } \\
\text { returns due to CU over } \\
\text { GW) (Rs.38266 - } \\
\text { Rs.28979) }\end{array}$} & \multirow{3}{*}{9287} \\
\hline Marketing cost (Rs. 1475 - Rs. 942) & 533 & & \\
\hline Human labour cost (Rs. 15751 - Rs.9439) & 6312 & & \\
\hline Total expenses & 10174 & Total savings & 12087 \\
\hline
\end{tabular}

SW: Surface water; CU: Conjunctive use of water 
Table.5 Estimated profitability of Paddy crop of CU farms over SW (Rs/acre)

\begin{tabular}{|c|c|c|c|}
\hline Debit & Amount (Rs) & Credit & Amount (Rs) \\
\hline \multicolumn{2}{|c|}{$\begin{array}{l}\text { Increase in cost } \\
\text { (Additional cost due to } \mathrm{CU} \text { over } \mathrm{GW} \text { ) }\end{array}$} & \multicolumn{2}{|c|}{$\begin{array}{c}\text { Decrease in cost } \\
\text { (Reduced cost due to CU over GW) }\end{array}$} \\
\hline Seeds (Rs. 1245 - Rs.1545) & 300 & $\begin{array}{l}\text { Human labour cost } \\
\text { (Rs.10358 - Rs.8636) }\end{array}$ & 1722 \\
\hline $\begin{array}{l}\text { Machine labour cost (Rs.6694 - } \\
\text { Rs.4416) }\end{array}$ & 2278 & $\begin{array}{l}\text { Bullock labor cost } \\
\text { (Rs.396-Rs.290) }\end{array}$ & 106 \\
\hline FYM and silt cost (Rs.3214- Rs.4211) & 997 & & \\
\hline Fertilizers cost (Rs.2658- Rs.2356) & 302 & \multirow{3}{*}{$\begin{array}{l}\text { Increase in gross returns } \\
\text { (Additional gross returns } \\
\text { due to CU over GW) } \\
\text { (Rs.48852- Rs.46966) }\end{array}$} & \multirow{3}{*}{1886} \\
\hline Irrigation cost (Rs.1075 -Rs.727) & 348 & & \\
\hline Marketing cost (Rs.3627-Rs.2885) & 742 & & \\
\hline Total expenses & 4967 & Total savings & 3714 \\
\hline
\end{tabular}

GW: Groundwater; CU: Conjunctive use of water

Table.6 Marginal productivity of irrigation across different irrigation regimes

\begin{tabular}{|c|l|c|c|}
\hline Sl. No. & \multicolumn{1}{|c|}{ Variables } & Coefficients & t stat \\
\hline $\mathbf{1}$ & Intercept & -3348.26 & -0.33 \\
\hline $\mathbf{2}$ & Water used (ac inch) & $369.22^{*}$ & 4.95 \\
\hline $\mathbf{3}$ & Intercept dummy for CU $\left(\mathrm{D}_{1}\right)(10)$ & 27548.56 & 1.78 \\
\hline $\mathbf{4}$ & Intercept dummy for GW $\left(\mathrm{D}_{2}\right)(10)$ & $31590.15^{*}$ & 2.33 \\
\hline $\mathbf{5}$ & Slope dummy for CU $\left(\mathrm{D}_{1} \mathrm{X}\right)$ & $229.72^{*}$ & 2.49 \\
\hline $\mathbf{6}$ & Slope dummy for GW $\left(\mathrm{D}_{2} \mathrm{X}\right)$ & $-316.71^{*}$ & -2.69 \\
\hline $\mathbf{7}$ & R Square & 0.64 & \\
\hline
\end{tabular}

Note: * indicates significant at 5 per cent.

Table.7 Comparison of net farm returns across two methods (Rs)

\begin{tabular}{|c|l|c|c|c|}
\hline S1. No. & \multicolumn{1}{|c|}{ Particulars } & CU & GW & SW \\
\hline $\mathbf{1}$ & $\begin{array}{l}\text { Estimated net farm returns } \\
\text { through production function }\end{array}$ & 151594 & 32738 & 38337 \\
\hline $\mathbf{2}$ & Actual net farm returns & 159828 & 31488 & 34336 \\
\hline
\end{tabular}

Note: SW- Surface Water, GW- Ground Water, CU- Conjunctive Use.

SW Net returns $(\mathrm{Rs})=-3,348+(369 \times 112.63)=38,237$

GW Net returns $(\mathrm{Rs})=-3,348+(369 \times 66.57)+31,590+(-316.71 \times 66.57)=32,738$

CU Net returns $(\mathrm{Rs})=-3,348+(369.23 \times 212.7)+27,549+(229.7 \times 212.7)=1,51,594$ 
Appendix

Table.1 Cost and Returns of selected crops under different irrigation regimes

\begin{tabular}{|l|c|c|c|c|c|c|c|c|}
\hline \multicolumn{1}{|c|}{ Particulars } & \multicolumn{3}{|c|}{ Paddy } & \multicolumn{3}{c|}{ Ragi } & \multicolumn{3}{c|}{ Sugarcane } \\
\hline Labour man days & SW & CU & SW & GW & CU & SW & GW & CU \\
\hline Total human labour cost & 45 & 39 & 43 & 44 & 52 & 40 & 29 & 28 \\
\hline Bullock labour cost & 10358 & 8636 & 11215 & 9439 & 15751 & 15623 & 11475 & 11853 \\
\hline Machine labour cost & 396 & 290 & 2098 & 933 & 3627 & 2972 & 3360 & 2873 \\
\hline Seeds and seed material & 4416 & 6694 & 3361 & 2988 & 2935 & 5658 & 6960 & 7544 \\
\hline FYM and silt & 1245 & 1545 & 370 & 287 & 340 & 9138 & 10420 & 9240 \\
\hline Fertilizers & 3214 & 4211 & 4870 & 3860 & 4226 & 8756 & 12340 & 9840 \\
\hline Irrigation cost & 2356 & 2658 & 2029 & 2229 & 2445 & 7670 & 8428 & 7348 \\
\hline Total variable cost & 727 & 1075 & 242 & 3015 & 268 & 1250 & 15160 & 7330 \\
\hline Total fixed cost & 24937 & 27536 & 25880 & 24349 & 31663 & 56680 & 74700 & 61822 \\
\hline Marketing cost & 5828 & 6192 & 3078 & 3188 & 3442 & 11666 & 11854 & 12361 \\
\hline Total cost & 2885 & 3627 & 1952 & 942 & 1475 & 10500 & 6268 & 9747 \\
\hline Returns & 33650 & 37355 & 30910 & 28557 & 36580 & 78846 & 92821 & 84435 \\
\hline Yield of main product (q) & & & & & & & & \\
\hline Gross returns & 19 & 21 & 11 & 10 & 11 & 495 & 436 & 543 \\
\hline Net returns & 46966 & 48852 & 32515 & 28979 & 38266 & 115578 & 98437 & 121635 \\
\hline Gross returns / rupee of total cost & 13316 & 11498 & 1605 & 422 & 1686 & 36732 & 5616 & 37200 \\
\hline Cost of production (Rs/q) & 1759 & 1.30 & 1.10 & 1.00 & 1.00 & 1.50 & 1.10 & 1.40 \\
\hline
\end{tabular}

SW: Surface water; GW: Groundwater; CU: Conjunctive use of water

\section{Marginal productivity of different irrigation regimes}

The Linear dummy variable regression model was employed to assess the contribution of different regimes of $\mathrm{SW}, \mathrm{GW}$ and $\mathrm{CU}$ to the farms net returns. Annual net returns of the farm were regressed on water used by the farm in the entire year by different sources. The intercept dummy coefficient captures the influence of technology on net returns realized per farm. The coefficient of multiple determinations $\left(\mathrm{R}^{2}\right)$ was 0.64 indicating that the water used under different regimes explained about 64 per cent of the variation in net returns per farm. CU shift the net returns up by Rs 27,548 per farm while groundwater shifts the net returns up by Rs 31,590 per farm. The total Marginal productivity of SW use was Rs 369 per ac inch of water; GW was
Rs 52 per ac inch whereas CU was Rs 598 per acre inch of water use (Table 6). Using production function analysis, the net returns realized was worked out. The results were revealed that the net returns realized per farm was more in CU use farmers (Rs.1, 51,594) followed by SW (Rs 38,237) and GW (Rs.32, 738). This was due to effective utilization of irrigation water and they cultivate the crops year-round which will make him to earn the income continuously and handsomely. The actual net farm returns estimated and production function analysis was nearly equal (Table 7). Hence, the conjunctive use was the superior technique over the two regimes of irrigation. This was economically substantial and the main objective of the study was to estimate the economic returns due to the technology of conjunctive use. 
In conclusion the conjunctive use is a single input to address the physical and economic scarcity of surface water (SW) and groundwater $(\mathrm{GW})$ and it offers the solution to a large extent to hurtful effects of SW and GW. This study aims at addressing the importance of conjunctive use in enhance the income of the farmer. This study examines the comparative economics of crops (Sugarcane, Ragi and Paddy) under different regimes at farm level in Cauvery command area of Karnataka. The findings reveals that net gain realized by the sugarcane farmers under conjunctive use of water as against of surface and groundwater about Rs.774 and 34,233 per ac / year and it is same for Ragi and Paddy crop. Incentivizing the conjunctive use of water wherever feasible by educating farmers particularly in canal command area to overcome the ill effects. The study also demonstrated the conjunctive use adaption to crops (Sugarcane, Ragi and Paddy) which results in improvement in the income thereby leading to sustainability in income generation.

\section{References}

Chandrakanth, M. G., 2009. Karnataka state water sector reform: Current status, emerging issues and needed strategies. International Water Management Institute (IWMI). Colombo, Sri Lanka.

Chandrakanth, M. G., 2015. Water resource economics. Springer, Delhi.

Jahangir, W. A., Turral, H. and Khan, S. 2003. Net gains from conjunctive use of surface water and groundwater. International Water Management, Lahore, p. 823-837.

Suhas, C., 2017, Institutional economic analysis of conjunctive use in Cauvery river basin of Karnataka. M.Sc. Thesis (Unpub.), Univ. Agric. Sci., Bengaluru.

\section{How to cite this article:}

Venkataraman, M. N., L. Muralidhar, A. D. Ranganatha and Gururaj, B. 2020. The Comparative Economic Profitability of CU Crops Vis-a-Vis SW and GW Crops in Karnataka: Partial Budgeting Analysis. Int.J.Curr.Microbiol.App.Sci. 9(12): 1538-1546. doi: https://doi.org/10.20546/ijcmas.2020.912.182 